\title{
Mutagenesis in Petunia $x$ hybrida Vilm. and isolation of a novel morphological mutant
}

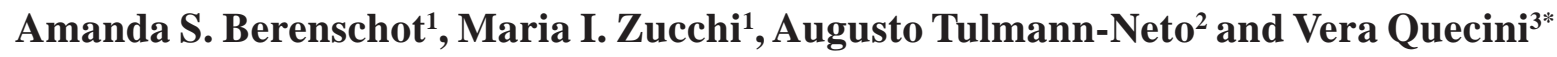

${ }^{1}$ Centro de P\&D Recursos Genéticos, Instituto Agronômico, CP 28, 13001-970 Campinas, SP, Brasil. ${ }^{2}$ Laboratório de Melhoramento de Plantas, CENA-USP, CP 96, 13400-970 Piracicaba, SP, Brasil. ${ }^{3}$ Present Address: CNPUV, EMBRAPA, Rua Livramento, 515, 95700-000 Bento Gonçalves, RS, Brasil. *Corresponding author: vera@cnpuv.embrapa.br

Received: 07 February 2008; Returned for revision: 30 April 2008; Accepted: 28 May 2008

Traditionally, mutagenesis has been used to introduce novel genetic variability in ornamental crops. More recently, it has become a powerful tool in gene discovery and functional analyses in reverse genetics approaches. The present work aimed to compare the efficiency of physical and chemical agents in generating mutant populations of petunia. We have indirectly evaluated the genomic damage by analyzing developmental characteristics of the plantlets derived from treated seeds employing gamma radiation at 0, 20, 40, 60, 80 and $100 \mathrm{~Gy}$ and the alkylating agent ethyl-methanesulfonate (EMS) at 0, 0.05, 0.1, 0.15, 0.2 and $0.25 \%(\mathrm{v} / \mathrm{v})$. Gamma rays and EMS caused developmental defects and decreased seedling viability in plants obtained from the mutagenized seeds. High mutagen doses reduced in approximately $44 \%$ the number of plants with primary leaves at 15 days after sowing (DAS) and decreased seedling survival rates to 55\% (gamma) and 28\% (EMS), in comparison to untreated controls. Seedling height decrease was proportional to increasing EMS dosage, whereas 40 and $60 \mathrm{~Gy}$ of gamma irradiation caused the most significant reduction in height. Moderate DNA damage allowing a high saturation of mutant alleles in the genome and the generation of viable plants for reverse genetics studies was correlated to the biological parameter $\mathrm{LD}_{50}$, the dose required to kill half of the tested population. It corresponded to $100 \mathrm{~Gy}$ for gamma radiation and $0.1 \%$ for EMS treatment. The optimized mutagen treatments were used to develop petunia mutant populations $\left(\mathrm{M}_{1}\right.$ and $\left.\mathrm{M}_{2}\right)$ and novel morphological mutants were identified.

Key words: EMS, gamma irradiation, genomic damage, mutagenesis, reverse genetics

Mutagênese em Petunia $x$ hybrida Vilm. e isolamento de um novo mutante morfológico. A mutagênese tem sido tradicionalmente usada para gerar variabilidade genética em plantas ornamentais. Recentemente, tornou-se uma ferramenta poderosa na descoberta e análise da função gênica em genética reversa. Este trabalho objetivou comparar a eficiência da mutagênese física e química na geração de populações mutantes de petúnia. O dano genômico foi avaliado indiretamente por características de desenvolvimento de plântulas após o tratamento com doses de radiação gama de 0, 20, 40, 60, 80 e 100 Gy e do agente alquilante etil-metanossulfonato (EMS) de 0; 0,05; 0,1; 0,15; 0,2 e 0,25\% (v/v). Radiação gama e EMS causaram danos ao desenvolvimento e reduziram a viabilidade das plântulas derivadas das sementes tratadas. As maiores doses de mutagênico diminuíram o número de plantas com folhas primárias aos 15 dias após a semeadura (DAS) em aproximadamente 44\% e reduziram as taxas de sobrevivência a 55\% (gama) e 28\% (EMS) em relação aos controles. A redução na altura das plântulas foi proporcional ao aumento das dosagens de EMS, enquanto 40 e 60 Gy de radiação gama provocaram a redução mais significativa na altura de plantas. Abordagens de genética reversa requerem danos genômicos moderados, que permitam alta saturação de alelos mutantes com pequena redução no número de plantas viáveis, relacionados ao parâmetro biológico $\mathrm{DL}_{50}$, dosagem de mutagênico necessária para eliminar metade da população. Este valor correspondeu a 100 Gy de radiação gama e $0,1 \%$ de EMS. Os tratamentos foram empregados para a geração de populações mutantes de petúnia $\left(M_{1}\right.$ e $\left.M_{2}\right)$ e novos mutantes morfológicos foram isolados.

Palavras-chave: dano genômico, EMS, genética reversa, mutagênese, radiação gama 


\section{INTRODUCTION}

Mutagenesis is highly instrumental in plant biology to induce genetic variability to a great number of crops, mainly due to the fact that the technology is simple, relatively cheap to perform, applicable to all plant species and equally usable on a small and large scale (Swaminatan, 1995, Siddiqui and Khan, 1999). The frequency and saturation of mutations can be regulated by varying the mutagen dose (Jander et al., 2003; Menda et al., 2004) and mutagenic agents can induce different extensions of genomic lesions, ranging from base mutations to larger fragment insertions or deletions (MacKenzie et al., 2005; Kim et al., 2006). Recently, a large amount of data derived from genome and expressed sequence tags (EST) sequencing projects has accumulated and allowed the development of highthroughput sequence-based mutant screens without $a$ priori phenotype analyses (Alonso and Ecker, 2006). The approach has been labeled "reverse genetics" and provides a platform for high-throughput analyses of gene function and isolation in wide range of plant species (Waugh et al., 2006). This application requires a high level of genome saturation with mutant alleles without compromising viability in later generations. In plants, the response to physical and chemical mutagens is speciesspecific and largely unknown for the majority of the species (Gilchrist and Haughn, 2005).

Petunia $x$ hybrida Vilm. is often considered a secondary plant model-system, due to various favorable biological features and the availability of technical tools for genomic, biochemical, cytogenetic and functional analyses (Angenent et al., 2005; Gerats and Vandenbussche, 2005). Moreover, it is commercially important as ornamental, representing an output greater than US\$148 million per year in the United States (USDA, 2005). Petunia is cultivated in flower beds and pots and requires full sunlight to produce plants and flowers with bright attractive colors, consistent with the prominent role of light in the regulation of several developmental and physiological processes, such as photomorphogenesis and seedling establishment and anthocyanin biosynthesis (Simkin et al., 2004; Underwood et al., 2005; Kanazawa et al., 2007).

Functional analyses of petunia genes have profited from the high abundance of endogenous transposable elements, however the transient nature of the insertion and the consequent instability of the phenotypes reduce its effectiveness (Alonso and Ecker, 2006). Moreover, insertion transposon-tagging approaches are effective to generate loss-of-function mutations by disruption of the gene or its regulatory sequences. A severe limitation of loss-offunction screens is that they rarely identify genes that act redundantly and sequencing of eukaryotic genomes has revealed the existence of many duplicated genes that are very similar both in their coding regions and their noncoding, regulatory regions (Weigel et al., 2000). Similarly, the analysis of genes whose function is required during multiple stages of the life cycle and whose loss of function results in early embryonic or in gametophytic lethality are difficult to be studied in loss-of-function mutants (Weigel et al., 2000). Therefore, other mutagen strategies are required. The present work aimed to investigate the genomic damage induced in petunia by physical and chemical agents and elaborate an effective protocol to generate saturate mutant populations for reverse genetic screens.

\section{MATERIAL AND METHODS}

Plant Material: Seeds of Petunia x hybrida 'Mitchell Diploid' (MD), a doubled haploid derived from the complex hybrid between $P$. axillaris and the cultivated variety "Rose of Heaven", kindly provided by Prof. Dr. David G. Clark of the Environmental Horticulture Department of University of Florida (USA), were employed in the mutagenesis treatments due to their high fertility, the effectiveness of in vitro culture protocols and high rates of genetic transformation (Gerats and Vandenbussche, 2005). Petunia MD plants were manually self-pollinated to increase seed setting and three flowers were bulked from each plant, according to petunia phyllotaxis.

Mutagenesis treatments: In order to determine the mutagen dosages to induce high saturation of mutant alleles in the petunia genome without significantly impairing plant viability, we assayed five increasing concentrations of gamma irradiation $(0,20,40,60,80$ and $100 \mathrm{~Gy})$ and EMS (0; 0.05, 0.10, 0.15, 0.20 and 0.25\% v/v) with seeds of Petunia $x$ hybrida MD fully randomized in four replicates of 25 seeds $(n=100)$. Dry seeds were submitted to gamma rays from the Cobalt-60 source at the 
Laboratory of Plant Breeding (CENA, University of São Paulo, Brazil). After the treatment, the seeds were individually sown in trays containing a moist mix of plant substrate: vermiculite (Eucatex, Brazil) (1:1), with a miniwand seeder (GRO MOR, Inc., MA, USA).

For EMS treatment, seeds were pre-imbibed in $500 \mu \mathrm{L}$ of sterile deionized water for at least $14 \mathrm{~h}$ in the dark with mild shaking (45 rpm) at room temperature. An adequate volume of a freshly-prepared EMS (Fluka, USA) stock solution at $0.5 \%(\mathrm{v} / \mathrm{v})$ was added to the pre-imbibed seeds to achieve the final concentration. The seeds were further incubated in the dark at room temperature for $24 \mathrm{~h}$ with mild shaking (45 rpm). After EMS treatment, the seeds were thoroughly rinsed (10 times with $1000 \mu \mathrm{L}$ ) with sterile deionized water and sown as described previously. Mutagen dosages equivalent to high saturation of mutant alleles and mild damage to plant viability were employed to generate M1 (1000 individuals), namely $100 \mathrm{~Gy}$ of gamma and $0.1 \%(\mathrm{v} / \mathrm{v})$ of EMS.

Evaluation of the genotoxic effect: Genome damage was indirectly evaluated by the effect of the mutagen treatments on developmental and physiological parameters in timecourse analyses from 1 to $30 \mathrm{~d}$ after sowing (DAS) and at 15 and 30 DAS for the following characteristics: seed germination (\%), emission of primary leaves (frequency and timing), plant survival (\%) and height (mm). The fertility of the plants from the M1 population was also evaluated by the rate of successful manual self-pollination. Data were individually scored and statistically analyzed by ANOVA and regression analyses. The regression analyses were used to calculate the lethal mutagen dosage for half of the studied population $\left(\mathrm{LD}_{50}\right)$. The plotted values represent the mean and the standard deviation for each treatment obtained from data of 100 plants randomly distributed in four independent replicates.

Phenotypic variability indicators: Induced variability was monitored in M1 and M2 populations in order to provide an indicator of the mutation density in the batch of individuals in the early stages without having to propagate the lines to advanced generations. The plants in M1 were manually selfpollinated and harvested in bulk, except for the novel described mutant with a winged stem and reduced apical dominance (wad). Common phenotypes produced by mutagenesis, such as those listed by Menda et al. (2004) and Wu et al. (2005) were scored and plants showing distinct inheritable phenotypes were separately advanced by self-pollination, as lines.

\section{RESULTS}

Phenotypic variation induced by gamma radiation and EMS: The effects of the mutagen dosage of gamma rays and EMS were easily perceived by visual evaluation of the seedlings and plantlets in a time-course analysis and at 15 and 30 DAS (Figure 1). However, a large number of plants recovered and reached a mature stage similar to the wild types. The timing of seed germination was significantly affected by both mutagens employed (Figure 1). Although gamma rays showed marked deleterious effects on the percentage of seed germination, the employed EMS dosages did not cause the same effect; they exhibited instead an approximately sigmoid pattern indicating that the alkylating agent had greater impact in slowing down

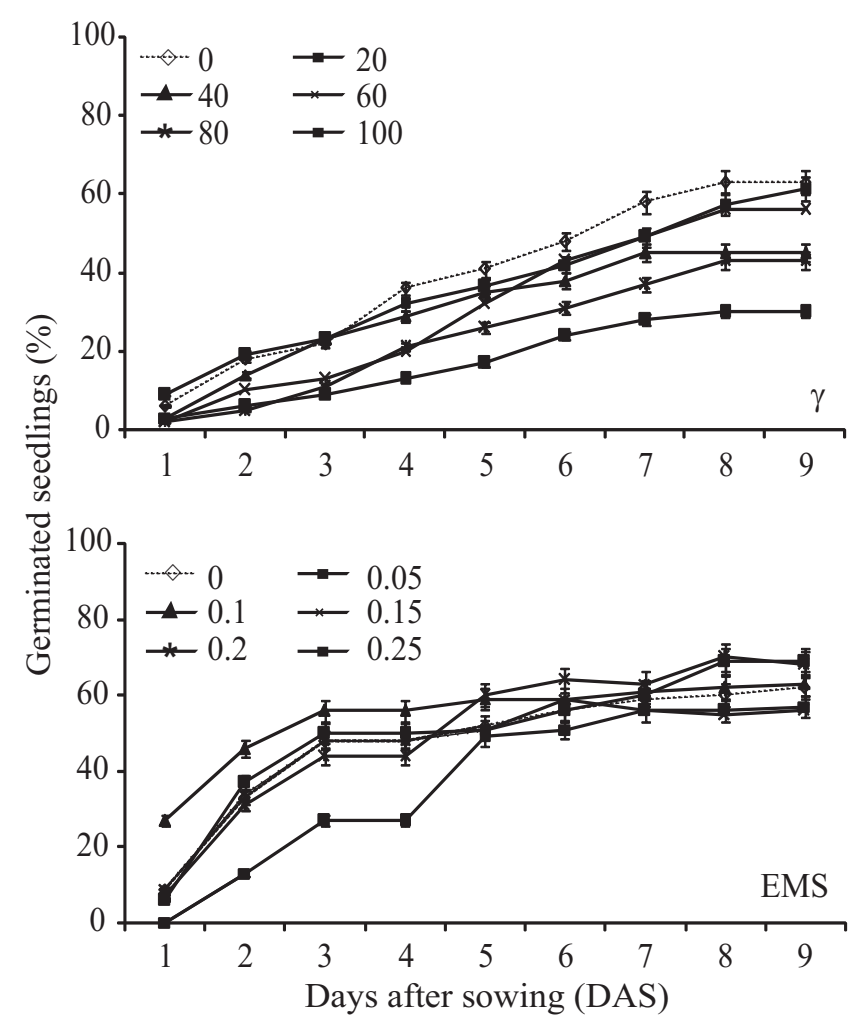

Figure 1. Time-course of Petunia $x$ hybrida MD seed germination after mutagen treatments in M1. The values represent the means of four independent replicates \pm SD $(n=100)$. 
the process rather than decreasing it (Figure 2, Table 1). In contrast, small and intermediate dosages of EMS slightly increased seed germination rates of $P$. $x$ hybrida seeds (Figure 1, Table 1).

Evaluation of the later stages of development of the mutagenized plants revealed that, although the germination rate was smaller for gamma treated-seeds, the plants that surpassed the early developmental constraints were able to survive at higher rates in comparison to EMS-treated plants (Table 1). Similarly, EMS treatment caused a greater decrease in plant height at 30 DAS (Table 1). Survival rates and plant height at 15 DAS exhibited a stochastic distribution for M1 populations derived from gamma and EMS treatments (Table 1). In general, the standard deviation for the plant height values was higher at 30 DAS than at 15 DAS, confirming the existence of dwarf plants that were fully mature but showing severe impairment in height (Table 1). The highest dosages of mutagen employed decreased plantlet survival rates to $55.6 \%$ (gamma) and $28.5 \%$ (EMS) at 30 DAS in comparison to untreated controls (Table 1) although not at a linear rate. Although plant height and survival rate at 30 DAS were close to linearity, the percentage of plants with primary leaves at 20 DAS, obtained from the time-course analysis, presented better linear correlation coefficients, $98.9 \%$ and $98.8 \%$ for gamma rays and EMS at $99 \%$ of probability, respectively (Figure 2). Interestingly, the observation was only valid for the time frame comprised between 15 and 25 DAS because at later stages of development, the surviving plants recovered and showed similar rates of leaf development (data not shown).

The most linear developmental parameter, namely, the number of plants with primary leaves at 20 DAS, was employed to calculate the mutagen dosage to kill half of the tested population $\left(\mathrm{LD}_{50}\right)$ of $P . x$ hybrida MD seeds according to the statistically significant linear regression equations of the percentage of plants with primary leaves and the mutagen dosages (Figure 2); $y=120.034-0.740 x$ for gamma irradiation and $y=77.001-244.000 x$ for EMS treatment, where $y$ represents the percentage of plants with primary leaves and $x$, the mutagen dosage.

Generation and overall characteristics of P. $x$ hybrida MD mutagenized populations: In order to generate mutant populations for reverse genetic screens, we submitted 1000 seeds of P. $x$ hybrida MD to gamma irradiation (100 Gy) and an equal amount of seeds to EMS treatment $(0.1 \% \mathrm{v} / \mathrm{v})$. The mutagenized seeds were sown and the morphological variability induced in M1 and M2 were evaluated for gamma- and EMS-generated populations. The vast majority of treated M1 plants exhibited reduced germination and growth rates due to the toxic effects of the mutagens, as observed in the smaller scale assay (Table 1).

At the adult vegetative stage, plant survival rate and the frequency of morphological effects were higher for the M1 population derived from gamma irradiation-treated seeds (Table 2). In contrast, fertility, indirectly evaluated by the effectiveness of manual self-pollination, was higher in EMSderived population (Table 2). In general, the ionizing agent gave rise to an approximately 2.4-fold higher frequency of phenotipically identified variation. However, the fertility of the gamma M1 population was about 1.3 times smaller, indicating that not all variability induced will be available for genetic analyses in the further generations (Table 2).

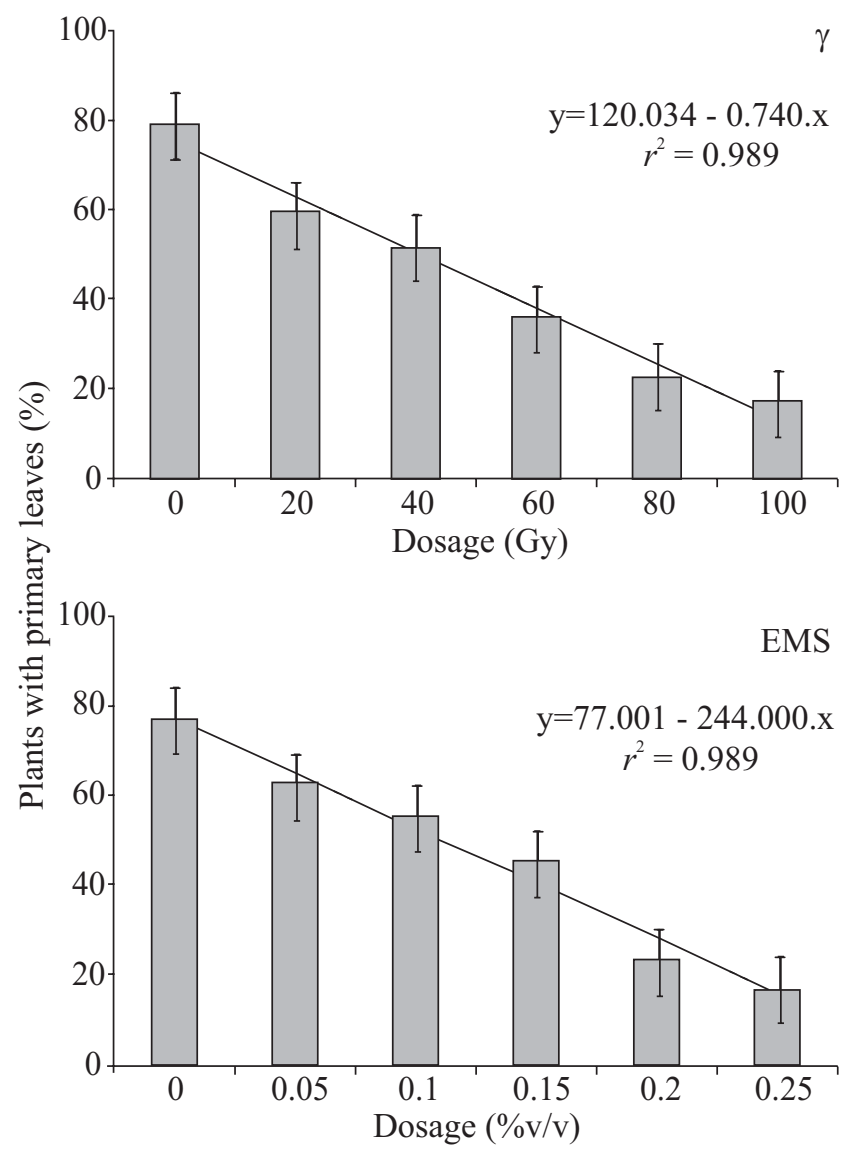

Figure 2. Percentage of Petunia x hybrida MD plants with primary leaves at 30 DAS after mutagen treatments in M1. The values represent the means of four independent replicates \pm SD $(n=100)$. The linear regression equations and the correlation coefficient at $0.01 \%$ of probability are shown. 
Table 1. Developmental effects of physical and chemical mutagenesis in $P$. $x$ hybrida. Germination percentage at 15 DAS (days after sowing), survival percentage, plant height at 15 and 30 DAS and fertility (\%) are represented. Statistical significance at $P<0.01$ is represented by different lower case letters.

\begin{tabular}{|c|c|c|c|c|c|c|}
\hline \multirow[t]{2}{*}{ Dosage } & \multirow[t]{2}{*}{ Germ. (\%) } & \multicolumn{2}{|c|}{ Survival (\%) } & \multicolumn{2}{|c|}{ Height (mm) } & \multirow[t]{2}{*}{ Fertility (\%)* } \\
\hline & & 15DAS & 30 DAS & 15 DAS & 30 DAS & \\
\hline \multirow{2}{*}{\multicolumn{7}{|c|}{$\gamma$ rays }} \\
\hline & & & & & & \\
\hline 0 & $63^{\mathrm{a}}$ & $100^{\mathrm{a}}$ & $100^{\mathrm{a}}$ & $47.4 \pm 12.63$ & $79.6 \pm 12.85$ & $100^{\mathrm{a}}$ \\
\hline 20 & $61^{\mathrm{a}}$ & $77.4^{\mathrm{b}}$ & $51.8^{\mathrm{e}}$ & $49.7 \pm 7.90$ & $72.5 \pm 5.47$ & $100^{\mathrm{a}}$ \\
\hline 40 & $45^{\mathrm{b}}$ & $77.4^{\mathrm{b}}$ & $85.2^{\mathrm{b}}$ & $37.2 \pm 6.02$ & $42.4 \pm 10.28$ & $62.4^{\mathrm{c}}$ \\
\hline 60 & $46^{\mathrm{b}}$ & $73.6^{\mathrm{b}}$ & $66.7^{\mathrm{c}}$ & $48.0 \pm 14.05$ & $40.5 \pm 6.36$ & $51.9^{d}$ \\
\hline 80 & $43^{\mathrm{b}}$ & $62.3^{\mathrm{b}}$ & $55.6^{\mathrm{d}}$ & $41.8 \pm 3.15$ & $63.6 \pm 7.83$ & $53.2^{\mathrm{d}}$ \\
\hline 100 & $30^{c}$ & $54.7^{c}$ & $55.6^{\mathrm{d}}$ & $39.8 \pm 6.55$ & $61.9 \pm 16.87$ & $45.3^{e}$ \\
\hline \multicolumn{7}{|c|}{ EMS } \\
\hline \multicolumn{7}{|l|}{$\%(\mathrm{v} / \mathrm{v})$} \\
\hline 0 & $62^{\mathrm{a}}$ & $100^{\mathrm{a}}$ & $100^{\mathrm{a}}$ & $33.0 \pm 6.02$ & $77.0 \pm 16.4$ & $100^{\mathrm{a}}$ \\
\hline 0.05 & $69^{\mathrm{a}}$ & $101.9^{\mathrm{a}}$ & $45.4^{\mathrm{b}}$ & $31.7 \pm 3.92$ & $60.8 \pm 12.23$ & $100^{\mathrm{a}}$ \\
\hline 0.10 & $63^{\mathrm{a}}$ & $90.6^{\mathrm{b}}$ & $32.2^{\mathrm{d}}$ & $24.5 \pm 8.97$ & $43.6 \pm 6.67$ & $97.2^{\mathrm{a}}$ \\
\hline 0.15 & $56^{\mathrm{a}}$ & $105.7^{\mathrm{a}}$ & $39.6^{c}$ & $25.4 \pm 7.82$ & $31.6 \pm 3.97$ & $91.5^{\mathrm{b}}$ \\
\hline 0.20 & $55^{\mathrm{a}}$ & $92.5^{\mathrm{b}}$ & $36.8^{c}$ & $20.9 \pm 5.42$ & $25.8 \pm 6.30$ & $90.3^{\mathrm{b}}$ \\
\hline 0.25 & $52^{\mathrm{b}}$ & $90.2^{\mathrm{b}}$ & $28.5^{d}$ & $22.1 \pm 4.43$ & $28.3 \pm 5.15$ & $74.6^{c}$ \\
\hline
\end{tabular}

*Assessed by the rate of seed capsules produced after manual pollination of five flowers.

Table 2. Characterization of the M1 populations of $P . x$ hybrida MD generated by gamma radiation and EMS treatment.

\begin{tabular}{lcccr}
\hline Mutagen & M1 seeds & $\begin{array}{c}\text { M1 plants* } \\
(\%)\end{array}$ & $\begin{array}{c}\text { Fertile M1 } \\
\text { plants* (\%) }\end{array}$ & $\begin{array}{c}\text { Number of morphological } \\
\text { variants (\%) }\end{array}$ \\
\hline$\gamma 100$ Gy & 1000 & $657(65.70)$ & $310(47.18)$ & $12(3.87)$ \\
EMS 0.1\% & 1000 & $592(59.20)$ & $466(78.71)$ & $5(1.07)$ \\
Totals & 2000 & $1249(62.45)$ & $776(62.13)$ & $17(2.19)$ \\
\hline
\end{tabular}

"Plants that produced viable adult individuals.

${ }^{* *}$ Assessed by the rate of seed capsules produced after manual pollination of five flowers.

Variability estimated by morphological mutations: The genetic variability of the mutant populations offers a rough estimate of the mutation density (mutations per megabase) (Wu et al., 2005). Morphological variation screens under greenhouse conditions have revealed an average of $2.19 \%$ of putative mutants across the two populations observed in M1 (Table 2). The estimation of induced variability is imprecise due to the presence of unevaluated conditional traits that require specific environmental conditions to be assessed, such as pathogen and herbivore responses. In M2, traits that encompass broader categories of biological processes, such as reduced apical dominance and dwarfism, were found at higher rates in both mutagenized populations (Table 3). The majority of the phenotype variation classes were found for $\gamma$ and EMS M2 populations but the frequencies of some specific biological processes varied (Table 3). At the vegetative stage of petunia growth, the most common phenotypes observed in M2 were albino, cop/ det/fus-like phenotypes, darker green leaves and higher anthocyanin contents in comparison with the wild type and various degrees of dwarfism (Table 3). The most commonly affected reproductive trait was fertility, although the precise causes of these phenotypes remain to be further investigated. As of the M2 population, plants displaying variation in flower color and morphology were absent from both gamma- and EMS-derived populations.

The visual survey of treated populations M1 and the bulk M2 derived from EMS treatment allowed us to isolate a previously unreported morphological mutation in $P . x$ hybrida MD that was genetically transmissible to the 
Table 3. Estimation of the induced variability by visual evaluation of altered morphology phenotypes in populations M2 of $P . x$ hybrida MD induced by gamma radiation and EMS treatment.

\begin{tabular}{lccc}
\hline & $\boldsymbol{\gamma}$ rays (100 Gy) & EMS (0.1\% v/v) & Total (\%) \\
\hline Phenotype Class $^{*}$ & M2 & M2 & 0.39 \\
\hline albino & 2 & 1 & 0.13 \\
cop/det/fus* ${ }^{* *}$-like & 1 & 0 & 0.26 \\
dark green leaves $_{\text {dwarf* }}^{* * *}$ & 1 & 1 & 0.39 \\
high anthocyanin & 2 & 1 & 0.13 \\
lethal & 0 & 1 & 0.13 \\
reduced apical dominance & 1 & 0 & 0.13 \\
other classes & 1 & 0 & 0.26 \\
Total (\%) & 1 & 1 & $\mathbf{1 4}(\mathbf{1 . 8 1})$ \\
\hline
\end{tabular}

${ }^{*}$ The frequency of each is based on visual evaluation of M2. The mutant wad is not included.

${ }^{* *}$ Class of Arabidposis loss-of-function mutants that present de-etiolated phenotype in the dark. The abbreviations stand for cop: constitutive photomorphogenesis; det: de-etiolated; fus: fusca.

${ }^{* * *}$ The class includes semi-dwarf phenotypes.

next generation (Figures 3 and 4). The mutants have increased density of trichomes on the aerial parts and abnormal regulation of branching, reduced apical dominance and disturbed patterns of determinacy, although the decussate phyllotaxis is retained in the older leaves (Figures 3 and 4). The mutant leaf blade is narrower, slightly hyponastic, exhibits undefined petioles and a more complex venation pattern in comparison to the cross-venulated pattern of the wild type (Figure 4). Interestingly, the stem presents leaf-like tissue-growth extensions bilaterally along its length and delayed flowering time (Figure 3, Figure 4). The mutation did not alter the adult plant root system (data not shown); although the seedling root phenotype remains to be further investigated. The mutation was labeled winged apical dominance (wad) and its genetic nature and determinants are subjects of undergoing investigations.

\section{DISCUSSION}

Chemical and ionizing radiation mutagenesis have been routinely used to generate genetic variability for breeding research and genetic studies, especially in ornamental crops (Jain and Spencer, 2006). Recently, with the completion of several genome and EST projects, the amount of sequence data has increased drastically and allowed the effective use of mutant populations to investigate gene function in high-throughput reverse genetic approaches (Alonso and Ecker, 2006). In petunia, gene function studies have profited from the endogenous system of transposable elements (van den Broeck et al., 1998) to characterize the genetic determinants of a wide range of biological processes (Baumann et al., 2007; Cartolano et al., 2007; Simons et al., 2007). Although highly effective, transposon tagging employing non-engineered sequences can only generate loss-of-function mutations and the unstable nature of the insertion may impair long-term genetic analyses (Alonso and Ecker, 2006). Moreover, in tomato, the closely related model organism for fleshy fruit plants, early attempts of genome saturation through insertional mutagenesis, such as T-DNA and transposon tagging, enhancer trapping, etc, have not been as successful as in Arabidopsis (Emmanuel and Levy, 2002). Therefore, effective protocols to generate petunia mutant populations suitable for reverse genetic screens are still lacking.

In order to increase the likelihood of inducing distinct types of genetic variation in $P$. $x$ hybrida, we have employed gamma rays, an ionizing radiation, and the alkylating agent EMS. Mutants induced by gamma radiation are often generated by deletion of large DNA fragments, up to $6 \mathrm{Mb}$ (Naito et al., 2005), whereas EMS induces the formation of $O$ alkyl adducts of the nucleotides leading to mispairing that preferentially cause C/G to T/A transitions (Waugh et al., 2006). Accordingly, we observed a much more drastic effect of the ionizing radiation than the alkylating agent on several 


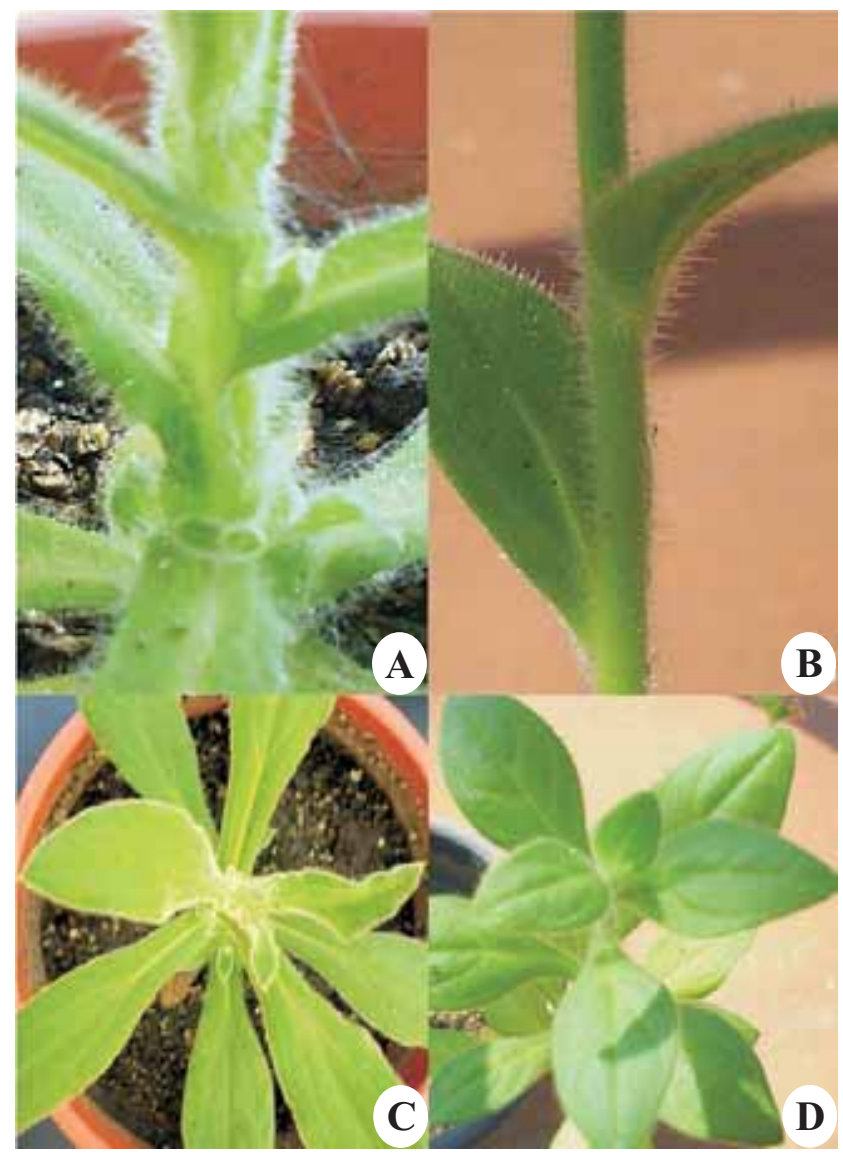

Figure 3. Whole-plant phenotype of the novel winged apical dominance mutant of Petunia x hybrida MD. (A) Mutant wad showing reduced apical dominance, higher trichome density and winged-stem and (B) wild-type stem and node. (C) Altered leaf shape and venation pattern of wad mutant and (D) wild-type petunia MD.

developmental processes evaluated in P. $x$ hybrida, as reported earlier by Kashikar and Khalatkar (1981). Moreover, weaker EMS treatments slightly accelerated seed germination, an effect observed for several abiotic stresses such as extreme temperature, water, salt, metal, ozone, gas $\left(\mathrm{SO}_{2}\right.$ and $\left.\mathrm{NO}_{\mathrm{x}}\right)$, etc., that generate cellular reactive oxygen species (ROS) or oxidative stress, which damage DNA indirectly (Mittler, 2002; Patra et al., 2005). The developmental and physiological effects of the mutagens on petunia were similar to those reported previously for petunia (Kashikar and Khalatkar, 1981; Napoli and Ruehle, 1996), other Solanaceae (Watanabe et al., 2007; Menda et al., 2004) and other species (Wu et al., 2006); namely, the more severe and deleterious effects were caused by $\gamma$-rays in comparison to EMS. However,

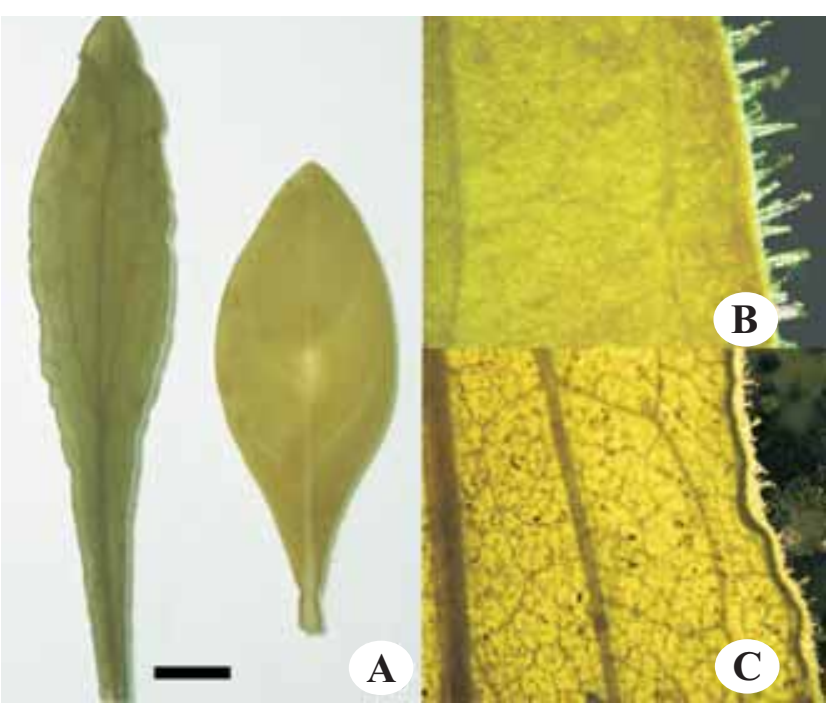

Figure 4. Leaf phenotypic traits of wad mutants. (A) Shape of the leaf blade of wad mutants (left) and wildtype (right) and cleared leaves of (B) wild type and (C) wad mutant, showing irregular leaf edge, higher trichome density and distinct venation pattern, observed under a stereomicroscope. Scale bar: $1 \mathrm{~cm}$ (A) and magnification $40 \mathrm{X}$ (B and C).

the unexpected greater effect of 0.2 and $0.25 \%(\mathrm{v} / \mathrm{v})$ of EMS may be attributed to the genomic instability caused by the mutagen in the activation of unusual transposable elements (Snowden et al., 2005). In contrast to the previous report of physical and chemical mutagenesis in petunia (Kashikar and Khalatkar, 1981), flower color mutants were not identified in our screens, in agreement with the fact that the generation of colored mutants from white-flowered lines is unexpected (Koes et al., 2005).

The presence of several classes of phenotypic variants suggests that the populations present adequate levels of genome saturation, however, the estimation of genetic variability is imprecise due to the presence of unevaluated conditional traits that require specific environmental conditions to be assessed, such as pathogen and herbivore responses (Waugh et al., 2006). Moreover, forward genetic bulk-screening procedures often result in low mutant yields due to the difficulties to detect minor effect mutations with certainty and to the fact that all sterile mutants are lost (Menda et al., 2004). Therefore, the genome saturation of the petunia MD populations remains to be further investigated by M2 and M3 family screens and allelism tests. 
A novel phenotype of plant architecture has been identified by direct genetic approaches and the mutant shows several modifications in the aerial parts, such as increased density of trichomes, abnormal regulation of branching, reduced apical dominance, distinct leaf shape and venation patterns and a winged stem. Determination of aerial growth patterns and architecture is a crucial developmental process within the plant body. Control of the type, position, and timing of shoot growth allows plants to develop in a dynamic manner that is defined genetically, but modulated environmentally (Kuhlemeier and Sinha, 2007). The developmental abnormalities observed in the wad mutant are reminiscent of alteration in phytohormone action. The pleiotropic phenotype of wad mutants bears similarities to those found in mutants with defective auxin homeostasis and polar transport, including aberrant leaf shape, venation pattern and apical dominance (Benjamins and Scheres, 2008). Although the association between auxin and trichome development remains unclear in Arabidopsis (Hülskamp et al., 2004), it has been established for tomato, cotton and other species (Serna and Martin, 2006; Lee et al., 2007). Patterns of plant branching and organ formation are diverse and still not fully understood (Angenent et al., 2005; Beveridge, 2006) and a series of petunia mutants has helped to uncover the genetic control of higher plant branching patterns (Napoli and Ruehle, 1996; Simons et al., 2007). The phenotypes of the novel mutant wad suggest that it will provide further comparison tools for the investigation of branching control and developmental growth regulation in plants.

Acknowledgements: Petunia research is supported by a FAPESP grant (2006/06306-0) to VQ. The present work is part of the MSc. dissertation of ASB in Tropical and Subtropical Agriculture at the Instituto Agronômico, Campinas, Brazil (area of Genetics, Plant Breeding and Biotechnology).

\section{REFERENCES}

Alonso JM, Ecker JR (2006) Moving forward in reverse: genetic technologies to enable genome-wide phenomic screens in Arabidopsis. Nat. Rev. Genet. 7:524-536.
Angenent GC, Stuurman J, Snowden KC, Koes R (2005) Use of Petunia to unravel plant meristem functioning. Trends Plant Sci. 10:243-250.

Baumann K, Perez-Rodriguez M, Bradley D, Venail J, Bailey P, Jin H, Koes R, Roberts K, Martin C (2007) Control of cell and petal morphogenesis by R2R3 MYB transcription factors. Development 134:1691-1701.

Benjamins R, Scheres B (2008) Auxin: the looping star in plant development. Annu. Rev. Plant Biol. 59:443-465.

Beveridge CA (2006) Axillary bud outgrowth: sending a message. Curr. Opin. Plant Biol. 9:35-40.

Cartolano M, Castillo R, Efremova N, Kuckenberg M, Zethof J, Gerats T, Schwarz-Sommer Z, Vandenbussche M (2007) A conserved microRNA module exerts homeotic control over Petunia hybrida and Antirrhinum majus floral organ identity. Nat. Genet. 39:901-905.

Emmanuel E, Levy AA (2002) Tomato mutants as tools for functional genomics. Curr. Opin. Plant Biol. 5:112-117.

Gerats T, Vandenbussche M (2005) A model system for comparative research: Petunia. Trends Plant Sci. 10:251-256.

Gilchrist EJ, Haughn GW (2005) TILLING without a plough: a new method with applications for reverse genetics. Curr. Opin. Plant Biol. 8:211-215.

Hülskamp M (2004) Plant trichomes: a model for cell differentiation. Nature Reviews. Mol. Cell Biol. 5:471480.

Jain SM, Spencer MM (2006) Biotechnology and mutagenesis in improving ornamental plants. In: Teixeira da Silva, JA (ed), Floriculture and Ornamental Biotechnology: Advances and Tropical Issues, pp.1749-2036. Global Science Books, London.

Jander G, Baerson SR, Hudak JA, Gonzalez KA, Gruys KJ, Last RL (2003) Ethylmethanesulfonate saturation mutagenesis in Arabidopsis to determine frequency of herbicide resistance. Plant Physiol. 131:139-146.

Kanazawa A, O’Dell M, Hellens RP (2007) Epigenetic inactivation of chalcone synthase-A transgene transcription in petunia leads to a reversion of the post-transcriptional gene silencing phenotype. Plant Cell Physiol. 48:638-647.

Kashikar SG, Khalatkar AS (1981) Breeding for flower color in Petunia hybrida Hort. Acta Hort. 111:35-40.

Kim Y, Schumaker KS, Zhu JK (2006) EMS mutagenesis of Arabidopsis. Meth. Mol. Biol. 323:101-103. 
Koes R, Verweij W, Quattrocchio F (2005) Flavonoids: a colorful model for the regulation and evolution of biochemical pathways. Trends Plant Sci. 10:236-242.

Kuhlemeier C, Sinha N (2007) Growth and development. The diversity of plant development. Curr. Opin. Plant Biol. 10:1-3.

Lee JJ, Woodward AW, Chen ZJ (2007) Gene expression changes and early events in cotton fibre development. Ann. Bot. 100:1391-401.

MacKenzie JL, Saadé FE, Le QH, Bureau TE, Schoen DJ (2005) Genomic mutation in lines of Arabidopsis thaliana exposed to ultraviolet-B radiation. Genetics 171:715-723.

Menda N, Semel Y, Peled D, Eshed Y, Zamir D (2004) In silico screening of a saturated mutation library of tomato. Plant J. 38:861-872.

Mittler R (2002) Oxidative stress, antioxidants and stress tolerance. Trends Plant Sci. 7:405-410.

Naito K, Kusaba M, Shikazono N, Takano T, Tanaka A, Tanisaka T, Nishimura M (2005) Transmissible and nontransmissible mutations induced by irradiating Arabidopsis thaliana pollen with g-rays and carbon ions. Genetics 169: 881-889.

Napoli CA, Ruehle J (1996) New mutations affect meristem growth and potential in Petunia hybrida Vilm. J. Hered. 87:371-377.

Patra J, Sahoo MK, Panda BB (2005) Salicylic acid triggers genotoxic adaptation to methyl mercuric chloride and ethyl methane sulfonate, but not to maleic hydrazide in root meristem cells of Allium cepa L. Mutat. Res. 581:173-180.

Serna L, Martin C (2006) Trichomes: different regulatory networks lead to convergent structures. Trends Plant Sci. 11:274-280.

Siddiqui BA, Khan S (1999) Breeding in Crop Plants: Mutations and in Vitro Mutation Breeding. $1^{\text {st }}$ ed. Kalyani Publishers, Ludhiana.

Simkin AJ, Underwood BA, Auldridge M, Loucas HM, Shibuya K, Schmelz E, Clark DG, Klee HJ (2004) Circadian regulation of the PhCCD1 carotenoid cleavage dioxygenase controls emission of betaionone, a fragrance volatile of petunia flowers. Plant Physiol. 136:3504-3514.

Simons JL, Napoli CA, Janssen BJ, Plummer KM, Snowden KC (2007) Analysis of the DECREASED APICAL DOMINANCE genes of petunia in the control of axillary branching. Plant Physiol. 143:697-706.

Snowden KC, Simkin AJ, Janssen BJ, Templeton KR, Loucas HM, Simons JL, Karunairetnam S, Gleave AP, Clark DG, Klee HJ (2005) The Decreased apical dominance1/Petunia hybrida CAROTENOID CLEAVAGE DIOXYGENASE8 gene affects branch production and plays a role in leaf senescence, root growth, and flower development. Plant Cell 17:746-759.

Swaminatan MS (1995) The detection of induced mutations. In: FAO/IAEA division of atomic energy in food and agriculture (ed), Manual on Mutation Breeding, pp.138-141. International Atomic Energy Agency, Vienna.

Underwood BA, Tieman DM, Shibuya K, Dexter RJ, Loucas HM, Simkin AJ, Sims CA, Schmelz EA, Klee HJ, Clark DG (2005) Ethylene-regulated floral volatile synthesis in petunia corollas. Plant Physiol. 138:255-266.

United States Department of Agriculture (USDA) (2005) National Agricultural Statistics Service, Floriculture Crops, http://usda.mannlib.cornell.edu/reports/nassr/ other/zfc-bb/.

van den Broeck D, Maes T, Sauer M, Zethof J, De Keukeleire P, D’hauw M, Van Montagu M, Gerats T (1998) Transposon Display identifies individual transposable elements in high copy number lines. Plant J. 13:121-129.

Watanabe S, Mizoguchi T, Aoki K, Kubo Y, Mori H, Imanishi S, Yamazaki Y, Shibata D, Ezural H (2007) Ethylmethanesulfonate (EMS) mutagenesis of Solanum lycopersicum cv. Micro-Tom for large-scale mutant screens. Plant Biotechnol. 24:33-38.

Waugh R, Leader DJ, McCallum N, Caldwell D (2006) Harvesting the potential of induced biological diversity. Trends Plant Sci. 11:71-79.

Weigel D, Ahn JH, Blázquez MA, Borevitz JO, Christensen SK, Fankhauser C, Ferrándiz C, Kardailsky I, Malancharuvil EJ, Neff MM, Nguyen JT, Sato S, Wang ZY, Xia Y, Dixon RA, Harrison MJ, Lamb CJ, Yanofsky MF, Chory J (2000) Activation tagging in Arabidopsis. Plant Physiol. 122:1003-1013.

Wu JL, Wu C, Lei C, Baraoidan M, Bordeos A, Madamba MR, Ramos-Pamplona M, Mauleon R, Portugal A, Ulat VJ, Bruskiewich R, Wang G, Leach J, Khush G, Leung H (2005) Chemical- and irradiation-induced mutants of indica rice IR64 for forward and reverse genetics. Plant Mol Biol. 59:85-97. 